This is an author produced version of a paper published in Trees Structure and Function. This paper has been peer-reviewed and is proofcorrected, but does not include the journal pagination.

Citation for the published paper:

Ladanai, S., Ågren, G. (2004) Temperature sensitivity of nitrogen productivity for Scots pine and Norway spruce. Trees - Structure and Function.

Volume: 18 Number: 3, pp 312-319.

http://dx.doi.org/10.1007/s00468-003-0308-5

Access to the published version may require journal subscription.

Published with permission from: Springer Verlag

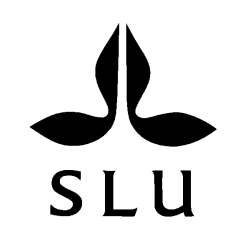

Epsilon Open Archive http://epsilon.slu.se 


\title{
Temperature sensitivity of nitrogen productivity for Scots pine and Norway spruce
}

\author{
Svetlana Ladanai \\ \& \\ Göran I. Ågren
}

Department of Ecology and Environmental Research
Swedish University of Agricultural Sciences
P.O. Box 7072
SE-750 07 Uppsala
Sweden
tel.: +4618673401
fax: +4618673430
E-mail: $\underline{\text { Sveta.Ladanai@eom.slu.se }}$

Submitted to Trees - structure and function/ 2003-03-18 


\begin{abstract}
Environmental conditions control physiological processes in plants and thus their growth. The predicted global warming is expected to accelerate tree growth. However, the growth response is a complex function of several processes with both direct and indirect effects. To analyse this problem we have used the nitrogen productivity, which is an aggregate parameter for tree growth. Data on needle dry matter, production, and nitrogen content in needles of Scots pine (Pinus sylvestris) and Norway spruce (Picea abies) from a wide range of climatic conditions were collected and needle nitrogen productivities, defined dry matter production of needles per unit of nitrogen in the needle biomass, were calculated. Our results show that the nitrogen productivity for spruce is insensitive to temperature. However, for pine, temperature affects both the magnitude of nitrogen productivity at low needle biomass and the response to self-shading but the temperature response is small at the high end of needle biomasses. For practical applications it may be sufficient to use a speciesspecific nitrogen productivity parameter that is independent of temperature. Because temperature affects tree growth also indirectly through soil processes, the effects of temperature change on tree growth and ecosystem carbon storage should mainly be derived from effects on nitrogen availability through changes in nitrogen mineralization. In addition, this paper summarises data on dry matter, production and nitrogen content of needles of conifer along a temperature gradient.
\end{abstract}

Keywords: climate change, needle biomass, nitrogen productivity, conifers, growth of trees. 


\section{Introduction}

Forest resources (e.g. Kuusela 1994; Kauppi et al. 1992) and tree growth (e.g. Spiecker et al. 1996; Mund et al. 2002) in Europe have been increasing during the past decades. In part this is a consequence of changes in management but improved growth conditions is another contributor. While the causes for the accelerating growth are still uncertain (e.g. Karjalainen et al. 1999), climate has been suggested as one of them.

Analyses of climate impact on tree increment started already in the middle of the 19th century (Bravais and Martins 1841; Beketov 1867; Pokorny 1869 (cited in Tarasov 1968)) and there is a huge literature dealing with this topic from very different perspectives. Most of this research has been directed towards deriving statistical and empirical relations between tree growth and climatic variables. However, these correlations showed no logical geographical or temporal patterns (Mäkinen 2003). Furthermore, the coming global climatic changes are likely to decrease the usefulness of existing yield tables for stand growth predictions (Chertov et. al. 1999). That is, these models reflect our current understanding of growth of trees, but not how trees will respond in the future. Instead explanation must be emphasised (Andersson et al. 2000). Thus, process-based simulation models are developed to overcome the limitations set by empirical models. Nevertheless, when climatic variables have been tested as predictors of growth, the climatic variables correlate with short- and medium-term growth variation, but long-term trends cannot be predicted (Spiecker et al. 1996).

A mechanistic approach requires a strict relation between causes and consequences (Kryazhimskii 2001). Maps created by Churkina and Running (1998) of weighted climatic controls indicate that temperature must be a major measure of climate for use in growth models. However, the growth response is a complex function of several processes and temperature affects many processes of importance for growth, some of which operate directly on the plants and others that operate indirectly through soil processes. These two types of processes are likely to operate at different time scales. Long-term effects of temperature may, therefore, differ considerably from the shortterm effects. Relationships between net production and mean annual climatic factors, which have been successful in predicting annual net production for a broad range of ecosystems in different climates (e.g. Lieth 1975), are purely statistical and do not separate the influence of different processes. There are just a few long-term studies of mechanisms of net carbon gain sensitivity to climatic conditions and these are generally focused on net photosynthesis (e.g. Teskey et al. 1994).

An important criterion when choosing a representation of a system is that it can be done with as few qualitatively different processes as possible (Ågren 1984). Hence, a possible approach is to use the strong relationship between growth and nutrients, notably nitrogen, in the plant (Ingestad 1979, 1980, 1981; Ågren 1983a; Wikström 1995) with nutrient supply as the link between plants and soil. Ågren (1983ab, 1985, 1998) formalized the growth response to nutrients in the nutrient productivity concept, which states that the relation between the plant's absolute growth rate and its content of nitrogen is linear. He also proposed that the proportionality factor in this relation (the nitrogen productivity) was conservative with respect to climate, but this 
suggestion has until now never been tested against empirical data. However, the practical advantage of such a simple predictor of plant growth is obvious.

Furthermore, given that environmental conditions control physiological processes in plants and thus their growth, there is a potential for temperature-driven changes in nitrogen productivity. In view of the concern about climatic change, it is important to test the temperature sensitivity of this parameter.

The primary objective of the present study is to test the temperature sensitivity of nitrogen productivity for different species. A second aim has been to collect biomass data from different climatic conditions.

\section{Materials and methods}

\section{Collection of the published data}

We have relied on literature data for conifers. Our analyses require information on needle biomass, needle growth, needle nitrogen content and temperature. We have only accepted needle data that have been obtained with direct sampling (trees were felled and needle were separated and weighted) and ignored data that have been derived from allometric equations. Some studies lacked climatic information and in this case we have relied on data from nearby meteorological stations. The result is data from 57 stands of Scots pine (Pinus sylvestris L.) and 46 stands of Norway spruce (Picea abies [L.] Karst.) see Appendix. Data for other species were not sufficient to allow further analysis.

\section{Nitrogen productivity}

The nitrogen productivity expresses quantitatively the limiting effect of nitrogen on growth (Ågren 1983a, 1985, 1988, 1994) through the following basic growth equation

$$
\frac{d W}{d t}=P_{N} N-c_{N, \min } W
$$

where $W$ is the dry weight of foliage, $N$ is the amount of nitrogen in foliage, $t$ time, $c_{N, \min }$ a certain minimum concentration of nitrogen in the foliage that is not active in growth and thus discounted, and $P_{N}$ is the nitrogen productivity, i.e., the growth rate is proportional to the amount of nitrogen in the plant, with the nitrogen productivity as a proportionality factor. A plant is thus characterised by two parameters, $P_{N}$ and $c_{N, \min }$, which under constant environmental conditions are constant. The parameter $c_{N, \min }$ is for most species small and can be neglected. On the other hand, because canopy size and architecture influences light interception, self-shading becomes important for larger canopies and the nitrogen productivity go down with the size of the canopy. Ågren (1983a) showed that this could be expressed as

$$
P_{N}=a-b W
$$

Where $a$ and $b$ are species-specific parameters. Using this model we will test the temperature sensitivity of nitrogen productivity by analysing the temperature sensitivity of the parameters $a$ and $b$. 


\section{Calculations}

The nitrogen productivity for a given stand, defined as the amount of biomass produced per amount of nitrogen in the plant per unit of time (Ågren 1983a), was calculated as (current needle biomass)/(total nitrogen in needle biomass). We used mean annual air temperature $(T)$ as climatic variable because this is the only temperature variable generally available.

\section{Results}

The calculated nitrogen productivities for two conifer species are given in the Appendix, Table 2 and Table 3. There is no suggestion for a relationship between temperature and nitrogen productivity for spruce in Fig. $1\left(r^{2}=0.03\right)$.

Fig.1 Nitrogen productivity as a function of temperature. Regressions: solid line and filled triangles $\left(P\right.$. sylvestris) $P_{N}=35.38-1.55 T, \mathrm{r}^{2}=0.27$; broken line and open triangles $\left(P\right.$. abies) $P_{N}=17.44-0.36 T, \mathrm{r}^{2}=0.03$

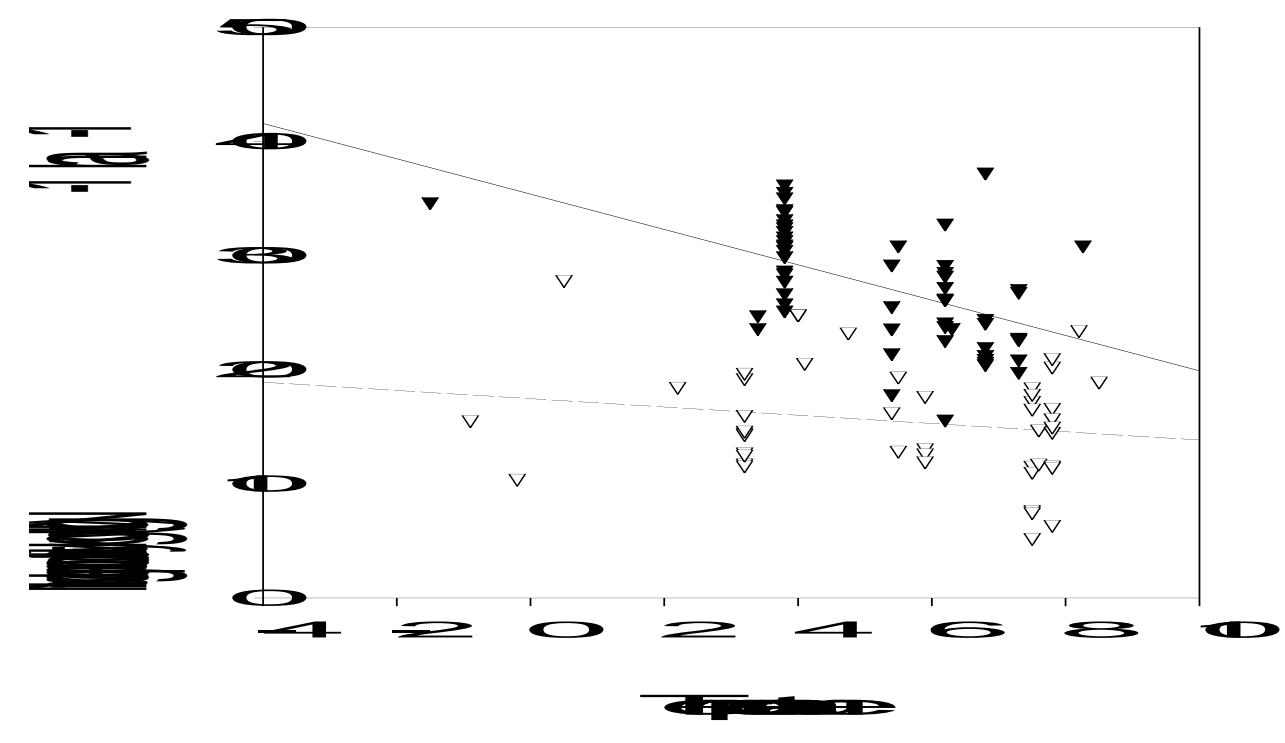

On the other hand, there is a weak trend of decreasing $P_{N}$ with $T$ for pine but there is a lot of scatter around the regression lines and much of the trend depends also on the single point at $\mathrm{T}=-1.5^{\circ} \mathrm{C}$. The scatter is a result of differences in canopy size for a given temperature. To remove the influence of canopy size, we have used Eq. (2). Because of the limited size of the data sets we have tested the effect of temperature by splitting each of the two data into two almost equally large parts by looking at $\mathrm{T}<5$ ${ }^{\circ} \mathrm{C}$ and $\mathrm{T}>5^{\circ} \mathrm{C}$. Figures 2 and 3 display the relation $P_{N}-W$ for pine and spruce stands, respectively. 
Fig. 2 The relation between nitrogen productivity and needle biomass for $P$. sylvestris stands. Regressions: solid line and filled circles $(\mathrm{T}<5) P_{N}=37.82-1.52 \mathrm{~W}, \mathrm{r}^{2}=0.38$; solid line and open circles $(\mathrm{T}>5) P_{N}=31.70-1.16 \mathrm{~W}, \mathrm{r}^{2}=0.26$; broken line and all circles (all T) $P_{N}=35.8-1.57 \mathrm{~W} ; \mathrm{r}^{2}=0.33$

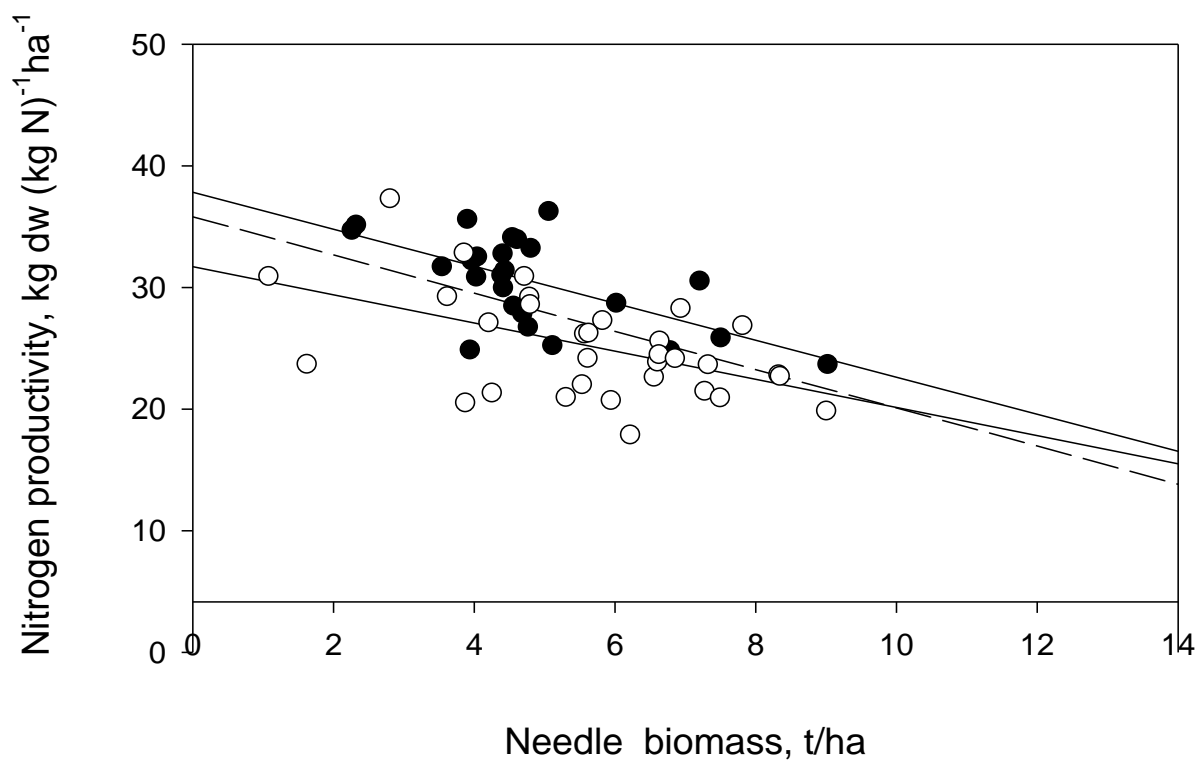

Fig. 3 The relation between nitrogen productivity and needle biomass for $P$. abies. Regressions: solid line and filled circles $(\mathrm{T}<5) P_{N}=21.22-0.43 \mathrm{~W}, \mathrm{r}^{2}=0.14$; solid line and open circles $(\mathrm{T}>5) P_{N}=17.59-0.23 \mathrm{~W}, \mathrm{r}^{2}=0.11$; broken line and all circles (all T) $P_{N}=19.80-0.37 \mathrm{~W} ; \mathrm{r}^{2}=0.16$

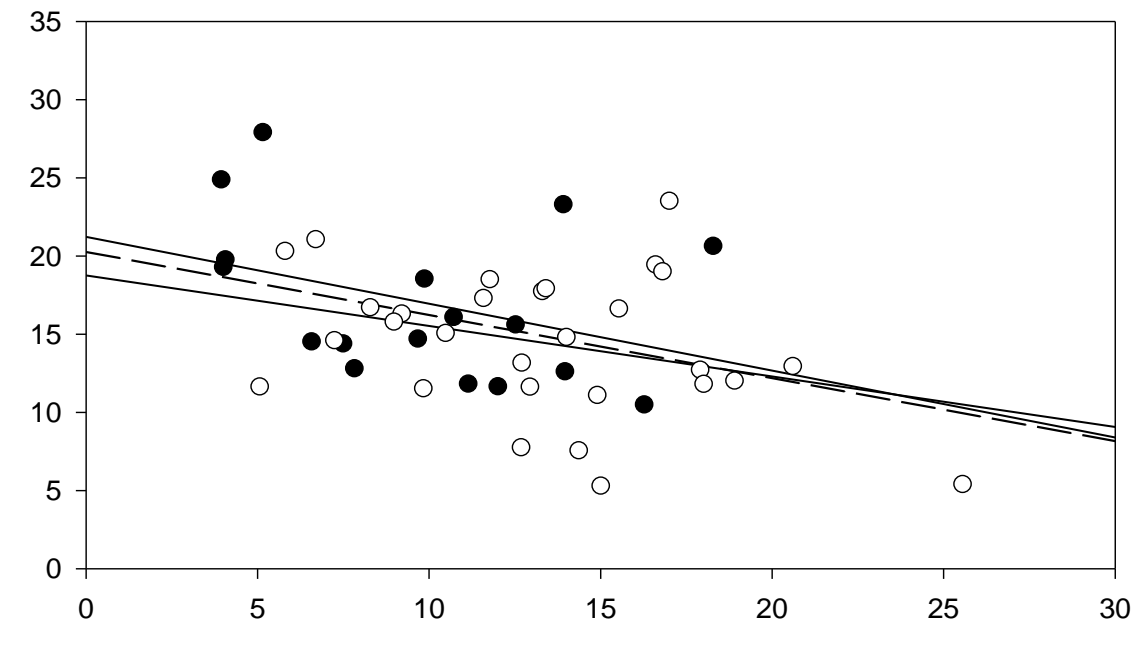


The negative relationship between nitrogen productivity and needle biomass is clear. An analysis of variance (Table 1) shows that the two temperature groups are significantly different only for Scots pine and that this difference can be attributed to both the intercepts and the slopes of the lines describing the relation between nitrogen productivity and needle biomass.

Table 1 Analysis of variance to compare a single regression line with separate regressions lines for $\mathrm{T}<5^{\circ} \mathrm{C}$ and $\mathrm{T}>5^{\circ} \mathrm{C}$

\begin{tabular}{|c|c|c|}
\hline $\begin{array}{l}\text { Source of } \\
\text { variation }\end{array}$ & Regressions for P. abies & Regressions for $P$. sylvestris \\
\hline $\begin{array}{l}\text { Single line versus } \\
\text { two different } \\
\text { lines }\end{array}$ & $\begin{array}{c}\text { All data: } P_{N}=19.80-0.37 \mathrm{~W} \\
T<5^{\circ} \mathrm{C}: P_{N}=21.22-0.43 \mathrm{~W} \\
T>5^{\circ} \mathrm{C}: P_{N}=17.59-0.23 \mathrm{~W} \\
\mathrm{~F}=0.98\end{array}$ & $\begin{array}{cc}\text { All data: } & P_{N}=35.8-1.57 \mathrm{~W} \\
T<5^{\circ} \mathrm{C}: & P_{N}=37.8-1.52 \mathrm{~W} \\
T>5{ }^{\circ} \mathrm{C}: & P_{N}=31.7-1.16 \mathrm{~W} \\
\mathrm{~F}=10.4 * * *\end{array}$ \\
\hline $\begin{array}{l}\text { Single line versus } \\
\text { two lines with } \\
\text { equal slopes }\end{array}$ & $\begin{array}{c}\text { All data: } P_{N}=19.80-0.37 \mathrm{~W} \\
T<5{ }^{\circ} \mathrm{C}: P_{N}=20.08-0.31 \mathrm{~W} \\
T>5{ }^{\circ} \mathrm{C}: P_{N}=18.55-0.31 \mathrm{~W} \\
\mathrm{~F}=1.83\end{array}$ & $\begin{array}{cc}\text { All data: } & P_{N}=35.8-1.57 \mathrm{~W} \\
T<5^{\circ} \mathrm{C}: & P_{N}=36.7-1.27 \mathrm{~W} \\
T>5{ }^{\circ} \mathrm{C}: & P_{N}=32.4-1.27 \mathrm{~W} \\
\mathrm{~F}=15.2 * * *\end{array}$ \\
\hline $\begin{array}{l}\text { Single line versus } \\
\text { two lines with } \\
\text { equal intercept }\end{array}$ & $\begin{array}{c}\text { All data: } P_{N}=19.80-0.37 \mathrm{~W} \\
T<5^{\circ} \mathrm{C}: P_{N}=19.43-0.27 \mathrm{~W} \\
T>5^{\circ} \mathrm{C}: P_{N}=19.43-0.37 \mathrm{~W} \\
\mathrm{~F}=1.24\end{array}$ & $\begin{array}{cc}\text { All data: } & P_{N}=35.8-1.57 \mathrm{~W} \\
T<5^{\circ} \mathrm{C}: & P_{N}=34.2-0.84 \mathrm{~W} \\
T>5^{\circ} \mathrm{C}: & P_{N}=34.2-1.56 \mathrm{~W} \\
\mathrm{~F}=12.5^{* * *}\end{array}$ \\
\hline
\end{tabular}

\section{Discussion}

\section{Comments on the collected database}

In spite of already existing large databases on forest biomass and production (Cannell 1982; Bazilevich 1993; Usoltsev 2001) there is rarely enough information available in these databases to allow estimations of parameters (Young and Beven 1994). Much of published data can be unsuitable because they correspond to specific forestry problem and vital pieces of information can be missing for certain further analyses. This study is the first one synthesising stand level needle biomass (total and current) and foliage nitrogen of Scots pine and Norway spruce for most of their temperature range. This database covers most of the natural geographical distribution of these species, spanning the entire width of Eurasia, although a wider range of climatic conditions would have been desirable. The estimation of needle biomasses is a problem due to lack of accurate methods. The mean tree method, which is the most common way to estimate biomass components, may introduce some uncertainty to stand-level needle biomass estimates (Zavitkovski et al. 1974 cited in Kuuluvainen 1990).

\section{Sensitivity of nitrogen productivity}

We found that temperature has no effect on the nitrogen productivity for Norway spruce. On the other hand, the nitrogen productivity for Scots pine is sensitive to temperature and the sensitivity affects both the magnitude at low needle biomass and the response to self-shading. What is surprising is that the nitrogen productivity seems 
to decrease with temperature except at the high end of the needle biomasses. We see two possible explanations.

First of all, it should be observed that nitrogen productivity represents the net carbon gain of a canopy and is therefore a balance between photosynthesis and respiration (Ågren 1996). Calculations with a model parameterised for Pinus taeda by Lou et al. (2001) indicate that under certain conditions net assimilation might go down with temperature and that, in general, the temperature response of net assimilation might not be that large anyhow. The observed decrease in temperature sensitivity of nitrogen productivity with increasing needle biomass and thus increasing canopy size, when shelf shading becomes important, support the suggestion that self-shading could limit the response of carbon assimilation to temperature (Ziska 1997). Ellsworth (2000), who found that warming affected the net carbon assimilation only during sunny days, provides a further indication. In natural environments changes in temperature are often accompanied by changes in light intensity. Our observation suggests that the pronounced impact of light availability on net assimilation exceed the impact of temperature. This is in consistent with Hennessey's observation (1991) that nonstomatal processes were a significant component of the rhythm in carbon assimilation, which did not occur spontaneously but must be induced and co-ordinated by an external stimulus. However, while cycles of light during growth entrained circadian rhythm in assimilation, a temperature cycle under constant light did not induce this rhythm.

Secondly, we are using temperature as a substitute for all climatic variables. However, increasing temperature may also be accompanied by water stress, which could lead to decreasing production with increasing temperature as a result of increased evaporative demands. Climatic changes, where current patterns of temperature and precipitation are altered, may therefore require a revision of our analyses.

It should be noted that the predicted higher sensitivity at low needle biomass depends on stands with either very young or very old trees (Appendix, Table 2). The observed decrease of sensitivity towards the high end of the needle biomasses could be a shift from a juvenile to an adult phase. That is, the net production of adult trees is less sensitive to changes in temperature than that of juvenile trees. Another observation pointing in this direction is provided by Ermolenko (1981) who found that the dry weight production of a unit of needles became independent of temperature at the age of a tree coinciding with the life span of needles for the species. Similarly, the higher sensitivity at the low needle biomass for the very old trees, might be attributable to ageing effects, when decline in needle mass is usual. However, these results must be taken with caution because they are based on only a small number of stands. Also, the main part of the ecophysiological knowledge is derived from measurements on seedlings during the juvenile phase and less is known about the response of mature trees to climate change (Källomäki 2000).

Finally, although the observed effect of temperature on nitrogen productivity for Scots pine seems to indicate a decrease with increasing temperature, there is a lot of scatter in the data, and over large ranges of needle biomasses the difference between high and low temperature is small. Moreover, much of the difference at low needle biomasses depends on a few data points. Therefore, for practical application it may be sufficient to use a nitrogen productivity that is independent of temperature. These 
results are obtained for two conifer species, but as these two species have rather different physiologies (e.g. sensitivity to shade) it is possible that other conifers also should show a similar insensitivity in nitrogen productivity.

Temperature is also influencing tree growth indirectly by its effect on decomposition of soil organic mater and mineralization of soil nutrients (Eberhardt et al. 2000). Our result suggests that this might be the mechanism through which long-term temperature effects operate. Unfortunately, there are no clear mechanisms explaining the response of nutrient uptake to soil temperature. Ingestad (1979) showed that the efficiency of the nutrient solution to supply nutrients is independent of temperature of the nutrient solution. Not surprisingly, there is a lot of contradiction in empirically derived relationships between net assimilation and soil temperature (e.g. Landhausser 2001; Man and Lieffers 1997; Day et al. 1990; DeLucia 1986; Grossnickle 2000). However, the major issue is probably how to obtain a correct estimation of the rate of nitrogen mineralization and thus the supply of nitrogen to the trees.

\section{Conclusion}

We have analysed the temperature response of the nitrogen productivity. Our main result is that the nitrogen productivity of conifers is not sensitive to temperature. This result supports the hypothesis that effects of temperature on the growth of trees are mediated by nutrient availability (Eberhardt et al. 2000). Indirect effects can be more important than direct one and efforts should therefore be focused on the processes occurring in the soil when estimating future growth stand.

\section{Acknowledgements}

This work was supported by the EU-financed project Recognition (FAIR6 CT984124). We thank Oleg Chertov and Alex Komarov for their help during the preparation of this manuscript and for comments on an earlier version of the paper. We appreciate comments by Vladimir Usoltsev and the particularly thoughtful remarks by Irina Ryzhova.

\section{References}

Ågren GI (1983a) Nitrogen productivity of some conifers. Can J For Res 13:494-500

Ågren GI (1983b) The concept of nitrogen productivity in forest growth modelling. Mitteilungen der forstlichen bundesversuchsanstalt 147:199-210

Ågren GI (1984) Forest growth and nutrient dynamics. In: Ågren GI (ed) State and Change in Forest Ecosystems - Indicators in Current Research. Report 79. Proceedings from the ESF workshop, Uppsala, Sweden, 21-24 march 1983. Swed Univ Agri Sci. Dep Ecology and Environmental Research, pp 111-119

Ågren GI (1985) Theory for growth of plants derived from the nitrogen productivity concept. Physiol Plant 64:17-28

Ågren GI (1988) The ideal nutrient productivities and nutrient proportions. Plant Cell Environ 11:613-620 
Ågren GI (1994) The interaction between $\mathrm{CO}_{2}$ and plant nutrition: comments on a papper by Coleman, McConnaughay and Bazzaz. Oecologia 98:239-240

Ågren GI (1996) Nitrogen productivity or photosysntes minus respiration to calculate plant growth? Oikos 76:529-535

Ågren GI, Bosatta E (1998) Theoretical ecosystem ecology. Understanding element cycles. Cambridge University Press, Cambridge

Andersson FO, Ågren GI, Erwin F (2000) Sustainable tree biomass production. For Ecol Manage 132:51-62

Bazilevich NI (1993) Biological productivity of Northern Eurasia ecosystems. Nauka, Moskva.

Cannell MGR (1982) World forest biomass and primary production data. Academic Press, London

Chertov OG, Komarov AS, Karev GP (1999) Modern approach in forest ecosystem modelling. European Forest Institute Research Report 8. Brill NV, Leiden Boston Köln, pp 98

Churkina G, Running SW (1998) Contrasting climatic controls on the estimated productivity of global terrestrial biomes. Ecosystems 1:206-215

Day TA, DeLucia EH, Smith WK (1990) Effect of soil temperature on stem sap flow, shoot gas exchange and water potencial of Picea engelmannii during snowmelt. Oecologia 84:474-481

DeLucia EH (1986) Effects of low root temperature on net photosyntesis, stomatal conductance and carbohydrate concentration in Engelman spruce (Picea engelmannii [P.] Engelm.) seedlings. Tree Physiol 2:526-533

Eberhardt MV, Lee CY, Liu RH (2000) Constraints to growth of boreal forests. Nature 405:904-905

Ellsworth DS (2000) Seasonal $\mathrm{CO}_{2}$ assimilation and stomatal limitations in a Pinus taeda canopy. Tree Physiol 20:435-445

Ermolenko PM, Ermolenko LG (1981) Vysotno-pojasnye osobennosti rosta kedra i pichty v zapadnom sajane. In: Polikarpov NP (ed) Formirovanie i

produktivnost drevostoev (in Russian). Nauka, Novosibirsk, pp 19-53

Grossnickle SC (2000) Ecophysiology of northern spruce species: the performance of planted seedlings. National Research Press, Ottawa Ontatio

Hennessey TL, Field CB (1991) Circadian rhythms in photosynthesis - oscillations in carbon assimilation and stomatal conductance under constant conditions. Plant Physiol 96:831-836

Ingestad T (1979) A definition of optimum nutrient requirements in birch seedlings. III. Influence of $\mathrm{pH}$ and temperature of nutrient solution. Physiol Plant 46:3135

Ingestad T (1980) Growth, nutrition, and nitrogen fixation in grey alder at varied rate of nitrogen addition. Physiol Plant 50:353-364

Ingestad T (1981) Nutrition and growth of birch and grey alder seedlings in low productivity solutions and at varied relative rates of nutrient addition. Physiol Plant 52:454-466

Källomäki S, Karjalainen T, Mohren F, Lapveteläinen T (2000) General assesment. In: Källomäki S, Karjalainen T, Mohren F, Lapveteläinen T (eds) Expert Assessments on the Likely Impacts of Climate Change on Forests and Forestry in Europe. EFI Proceedings 34. European Forest Institute, Joensuu, pp 18-20

Karjalainen T, Spiecker H, Laroussinie O (1999) Causes and consequences of accelerating tree growth in Europe. Proceedings of the international seminar 
held in Nancy, France 14-16 May 1998. EFI Proceedings 27. European Forest Institute, pp 286-287

Kaupi PE, Mielikäinen K, Kuusela K (1992) Biomass and carbon budget of European forests 1971 to 1990 . Science 256:70-74

Kryazhimskii FA, Bol'shakov VN, Koryukin VI (2001) Man in the light of current ecological problems. Russian J Ecol 32:369-374

Kuuluvainen T (1990) Long-term development of needle mass, radiation interception and stemwood production in naturally regenerated Pinus sylvestris stands on Empetrum-Vaccinium site type in the northern boreal zone in Finland: an analysis based on an empirical study and simulation. For Ecol Manage 46:103122

Kuusela K (1994) Forest resourses in Europe 1950-1990. EFI Research raport 1. Cambridge University Press, Cambridge New York Melbourne

Landhausser SM, DesRochers A, Leiffers VJ (2001) A comparison of growth and physiology in Picea glauca and Populus tremuloides at different soil temperature. Can J For Res 31(111):1922-1929

Lieth H (1975) Modeling the primary productivity of the world. In: Lieth H, Whittaker RH (eds) Primary Productivity of the Biosphere. Ecological Studies, vol 8. Springer, Berlin Heidelberg New York, pp 237-263

Lou Y, Medlyn BE, Hui D, Ellsworth DS, Reynolds J, Katul G (2001) Gross primary productivity in Duke forest: modelling synthesis of $\mathrm{CO}_{2}$ experiment and eddyflux data. Ecol Applic 11:239-252

Mäkinen H, Nöjd P, Kahle HP, Neuman U, Tveite B, Mielikäinen K, Röhle H, Spiecker H (2002) Large-scale climatic variability and radial increment variation of Picea abies (L.) Karst. in central and northern Europe. Trees 17:173-184

Man R, Lieffers VI (1997) Seasonal variation of photosynthetic capacities of white spruce (Picea glauca) and jack pine (Picea banksiana) saplings. Can J Bot 75:1766-1771

Mund M, Kummetz E, Hein M, Bauer GA, Schulze ED (2002) Growth and carbon stocks of a spruce forest chronosequence in central Europe. For Ecol Manage 171:275-296

Spiecker H, Mielikäinen K, Köhl M, Skovsgaard JP (eds) (1996) Growth Trends in European Forests - Studies from 12 Countries. EFI Research Report 5. Springer, Berlin Heidelberg New York, pp 372

Tarasov AI (1968) Variability of year increment of spruce in diameter in connection with degree of trees' suppression and weather alterations (in Russian). Lesovedenie 2:24-32

Teskey RO, Gholz HL, Cropper WP (1994) Influence of climate and fertilization on net photosynthesis of mature slash pine. Tree Physiol 14:1215-1227

Usoltsev VA (2001) Forest bioproductivity of Northern Eurasia: database and geography. Uro PAN, Yekaterinburg

Wikström F, Ågren GI (1995) The relationship between the growth rate of young plants and their total-N concentrations is unique and simple: a comment. Ann Bot 75:541-544

Young PC, Beven KJ (1994) Data-based mechanistic modelling and rainfall-flow non-linearity. Environmetrics 5:335-363

Ziska LB, Bunce JA (1997) The role of temperature in determining the stimulation of $\mathrm{CO}_{2}$ assimilation at elevated carbon dioxide concentration in soybean seedlings. Physiol Plant 100:126-132 
2011-01-18 13:26 


\section{Appendix}

Table 2 Mean annual temperature $T\left({ }^{\circ} \mathrm{C}\right)$, total and current needle biomasses $(\mathrm{t} / \mathrm{ha})$, amount of nitrogen in needle biomass $(\mathrm{kg} / \mathrm{ha})$, nitrogen productivity $\left(P_{N}\right)$ in Pinus sylvestris stands of different ages (years)

\begin{tabular}{|c|c|c|c|c|c|c|c|}
\hline Location & Age & $T$ & $\begin{array}{c}\text { Total } \\
\text { needle }\end{array}$ & $\begin{array}{c}\text { Current } \\
\text { needle }\end{array}$ & $\begin{array}{c}\text { Amount } \\
\text { of } \mathrm{N} \text { in } \\
\text { needle }\end{array}$ & $\boldsymbol{P}_{N}$ & $\begin{array}{c}\text { Literature } \\
\text { citation }\end{array}$ \\
\hline Russia, W.Siberia, Tomsk & 130 & -1.5 & 2.26 & 0.85 & 24.48 & 34.72 & Pyavchenko,1967 \\
\hline Russia, Yaroslavl & 57 & 3.4 & 6.78 & 2.39 & 96.28 & 24.82 & Utkin, 1988 \\
\hline Russia, Yaroslavl & 41 & 3.4 & 9.02 & 3.42 & 144.32 & 23.70 & Utkin, 1988 \\
\hline Finland, South & 28 & 3.8 & 2.32 & 0.90 & 25.60 & 35.16 & Mälkönen, 1974 \\
\hline Finland, South & 45 & 3.8 & 3.54 & 1.38 & 43.50 & 31.72 & Mälkönen, 1974 \\
\hline Finland, South & 48 & 3.8 & 3.90 & 1.75 & 49.11 & 35.63 & Mälkönen, 1991 \\
\hline Finland, South & 48 & 3.8 & 3.96 & 1.72 & 55.27 & 32.21 & Mälkönen, 1991 \\
\hline Finland, South & 47 & 3.8 & 4.03 & 1.57 & 50.73 & 30.87 & Mälkönen, 1974 \\
\hline Finland, South & 47 & 3.8 & 4.04 & 1.66 & 50.87 & 32.53 & Mälkönen, 1974 \\
\hline Finland, South & 48 & 3.8 & 4.39 & 1.72 & 55.27 & 31.03 & Mälkönen, 1991 \\
\hline Finland, South & 48 & 3.8 & 4.40 & 1.82 & 55.46 & 32.78 & Mälkönen, 1991 \\
\hline Finland, South & 47 & 3.8 & 4.41 & 1.67 & 55.55 & 29.99 & Mälkönen, 1974 \\
\hline Finland, South & 47 & 3.8 & 4.43 & 1.67 & 55.55 & 31.41 & Mälkönen, 1974 \\
\hline Finland, South & 48 & 3.8 & 4.54 & 1.72 & 55.27 & 34.13 & Mälkönen, 1991 \\
\hline Finland, South & 47 & 3.8 & 4.55 & 1.64 & 57.37 & 28.50 & Mälkönen, 1974 \\
\hline Finland, South & 48 & 3.8 & 4.60 & 1.97 & 58.02 & 33.97 & Mälkönen, 1991 \\
\hline Finland, South & 68 & 3.8 & 4.68 & 1.64 & 58.99 & 27.85 & Mälkönen, 1974 \\
\hline Finland, South & 68 & 3.8 & 4.76 & 1.61 & 59.99 & 26.75 & Mälkönen, 1974 \\
\hline Russia, Moskva & 17 & 3.8 & 4.80 & 2.24 & 67.40 & 33.24 & Sudnitsyna, 1967 \\
\hline Finland, South & 48 & 3.8 & 5.05 & 2.31 & 63.68 & 36.28 & Mälkönen, 1991 \\
\hline Finland, South & 68 & 3.8 & 5.11 & 1.62 & 64.35 & 25.24 & Mälkönen, 1974 \\
\hline Finland, South & 68 & 3.8 & 6.02 & 2.18 & 75.80 & 28.73 & Mälkönen, 1974 \\
\hline Russia, Moskva & 17 & 3.8 & 7.20 & 2.74 & 89.70 & 30.55 & Sudnitsyna, 1967 \\
\hline Russia, Moskva & 17 & 3.8 & 7.50 & 2.61 & 100.90 & 25.87 & Sudnitsyna, 1967 \\
\hline Sweden, Jädraås & $120-150$ & 4.0 & 3.94 & 1.26 & 50.70 & 24.89 & Bringmark, 1977 \\
\hline Sweden, Lisselbo E40 & 25 & 5.4 & 3.61 & 1.19 & 40.70 & 29.26 & Albrektson, 1977 \\
\hline Sweden, Lisselbo E40 & 25 & 5.4 & 6.21 & 2.42 & 134.90 & 17.90 & Albrektson, 1977 \\
\hline Sweden, Lisselbo E40 & 25 & 5.4 & 6.63 & 2.53 & 98.80 & 25.62 & Albrektson, 1977 \\
\hline Sweden, Lisselbo E40 & 25 & 5.4 & 7.27 & 2.50 & 116.10 & 21.49 & Albrektson, 1977 \\
\hline Sweden, Lisselbo E40 & 25 & 5.4 & 7.31 & 2.30 & 97.10 & 23.67 & Albrektson, 1977 \\
\hline Byelorussia, Smolevichi & 6 & 5.5 & 1.08 & 0.43 & 13.90 & 30.94 & Yurkevich, 1974 \\
\hline Byelorussia, Vasilevichi & 53 & 6.2 & 3.85 & 1.91 & 58.14 & 32.85 & Smoljak, 1978 \\
\hline Byelorussia, Vasilevichi & 44 & 6.2 & 4.78 & 2.11 & 72.18 & 29.23 & Smoljak, 1978 \\
\hline Byelorussia, Vasilevichi & 43 & 6.2 & 4.79 & 2.07 & 72.33 & 28.62 & Smoljak, 1978 \\
\hline Byelorussia, Vasilevichi & 42 & 6.2 & 5.56 & 2.20 & 83.96 & 26.20 & Smoljak, 1978 \\
\hline Byelorussia, Vasilevichi & 27 & 6.2 & 5.61 & 2.05 & 84.71 & 24.20 & Smoljak, 1978 \\
\hline Byelorussia, Vasilevichi & 56 & 6.2 & 5.62 & 2.23 & 84.86 & 26.28 & Smoljak, 1978 \\
\hline Byelorussia, Vasilevichi & 36 & 6.2 & 5.82 & 2.40 & 87.88 & 27.31 & Smoljak, 1978 \\
\hline Byelorussia, Ozarichi & 54 & 6.2 & 6.55 & 2.24 & 98.91 & 22.65 & Smoljak, 1978 \\
\hline Byelorussia, Ozarichi & 51 & 6.2 & 6.60 & 2.38 & 99.66 & 23.88 & Smoljak, 1978 \\
\hline Byelorussia, Ozarichi & 51 & 6.2 & 6.93 & 2.96 & 104.63 & 28.29 & Smoljak, 1978 \\
\hline Byelorussia, Osipovichi & 8 & 6.3 & 1.62 & 0.50 & 21.06 & 23.71 & Yurkevich, 1974 \\
\hline Ukraina, Roven' & 90 & 6.8 & 2.80 & 1.90 & 50.90 & 37.33 & Smoljaninov, 1969 \\
\hline Byelorussia, Ivacevichi & 43 & 6.8 & 3.87 & 1.20 & 58.44 & 20.53 & Smoljak, 1978 \\
\hline Byelorussia, Ivacevichi & 60 & 6.8 & 4.25 & 1.37 & 64.18 & 21.35 & Smoljak, 1978 \\
\hline Byelorussia, Ivacevichi & 47 & 6.8 & 5.30 & 1.68 & 80.03 & 20.99 & Smoljak, 1978 \\
\hline Byelorussia, Ivacevichi & 64 & 6.8 & 5.53 & 1.84 & 83.50 & 22.04 & Smoljak, 1978 \\
\hline Byelorussia, Ivacevichi & 43 & 6.8 & 5.94 & 1.86 & 89.69 & 20.74 & Smoljak, 1978 \\
\hline Byelorussia, Ivacevichi & 44 & 6.8 & 6.62 & 2.45 & 99.96 & 24.51 & Smoljak, 1978 \\
\hline Byelorussia, Ivacevichi & 45 & 6.8 & 6.85 & 2.50 & 103.44 & 24.17 & Smoljak, 1978 \\
\hline Byelorussia, Kobrichi & 47 & 7.3 & 4.20 & 1.72 & 63.42 & 27.13 & Smoljak, 1978 \\
\hline Byelorussia, Kobrichi & 49 & 7.3 & 7.49 & 2.37 & 113.10 & 20.96 & Smoljak, 1978 \\
\hline Byelorussia, Kobrichi & 50 & 7.3 & 7.81 & 3.17 & 117.93 & 26.88 & Smoljak, 1978 \\
\hline Byelorussia, Kobrichi & 50 & 7.3 & 8.32 & 2.87 & 125.63 & 22.84 & Smoljak, 1978 \\
\hline Byelorussia, Kobrichi & 49 & 7.3 & 8.34 & 2.86 & 125.93 & 22.71 & Smoljak, 1978 \\
\hline Byelorussia, Kobrichi & 40 & 7.3 & 9.00 & 2.70 & 135.90 & 19.87 & Smoljak, 1978 \\
\hline Scotland, Morayshire & 64 & 8.2 & 4.71 & 1.56 & 50.44 & 30.93 & Wright et.al., 1958 \\
\hline
\end{tabular}


Table 3 Mean annual temperature $T\left({ }^{\circ} \mathrm{C}\right)$, total and current needle biomasses $(\mathrm{t} / \mathrm{ha})$, amount of nitrogen in needle biomass $(\mathrm{kg} / \mathrm{ha})$, nitrogen productivity $\left(P_{N}\right)$ in Picea abies stands of different ages (years)

\begin{tabular}{|c|c|c|c|c|c|c|c|}
\hline Location & Age & $T$ & $\begin{array}{c}\text { Total } \\
\text { needle }\end{array}$ & $\begin{array}{c}\text { Current } \\
\text { needle }\end{array}$ & $\begin{array}{l}\text { Amount } \\
\text { of } N \text { in } \\
\text { needle }\end{array}$ & $\boldsymbol{P}_{N}$ & $\begin{array}{l}\text { Literature } \\
\text { citation }\end{array}$ \\
\hline Sweden, Stråsan, E26A & $10-15$ & 3.2 & 4.06 & 0.87 & 44 & 19.77 & Tamm, 1974 \\
\hline Sweden, Stråsan, E26A & $10-15$ & 3.2 & 4.00 & 0.83 & 43 & 19.30 & Tamm, 1974 \\
\hline Sweden, Stråsan, E26A & $10-15$ & 3.2 & 7.49 & 1.57 & 109 & 14.40 & Tamm, 1974 \\
\hline Sweden, Stråsan, E26A & $10-15$ & 3.2 & 10.71 & 2.51 & 156 & 16.09 & Tamm, 1974 \\
\hline Sweden, Stråsan, E26A & $10-15$ & 3.2 & 13.96 & 3.43 & 272 & 12.61 & Tamm, 1974 \\
\hline Sweden, Stråsan, E26A & $10-15$ & 3.2 & 7.82 & 1.96 & 153 & 12.81 & Tamm, 1974 \\
\hline Sweden, Stråsan, E26A & $10-15$ & 3.2 & 11.14 & 2.78 & 235 & 11.83 & Tamm, 1974 \\
\hline Sweden, Stråsan, E26A & $10-15$ & 3.2 & 12.00 & 2.95 & 253 & 11.66 & Tamm, 1974 \\
\hline Sweden, Stråsan, E26A & $10-15$ & 3.2 & 9.67 & 2,78 & 189 & 14.71 & Tamm, 1974 \\
\hline Sweden, Stråsan, E26A & $10-15$ & 3.2 & 6.57 & 1.86 & 128 & 14.53 & Tamm, 1974 \\
\hline UK, Thetford Chase & 11 & 3.2 & 5.80 & 2.54 & 125 & 20.32 & Ovington, 1957 \\
\hline UK, Thetford Chase & 14 & 7.8 & 6.69 & 3.16 & 150 & 21.07 & Ovington, 1957 \\
\hline UK, Thetford Chase & 17 & 7.8 & 8.97 & 3.95 & 250 & 15.80 & Ovington, 1957 \\
\hline UK, Thetford Chase & 20 & 7.8 & 10.48 & 4.37 & 290 & 15.07 & Ovington, 1957 \\
\hline UK, Thetford Chase & 23 & 7.8 & 5.06 & 2.62 & 225 & 11.64 & Ovington, 1957 \\
\hline Sweden, Hökaberg, E1 & 23 & 7.5 & 13.4 & 2.60 & 145 & 27.85 & Mälkönen, 1974 \\
\hline Sweden, Hökaberg, E1 & 23 & 7.5 & 11.77 & 2.35 & 127 & 26.75 & Mälkönen, 1974 \\
\hline Sweden, Hökaberg, E1 & 23 & 7.5 & 11.58 & 2.25 & 130 & 33.24 & Sudnitsyna, 1967 \\
\hline Sweden, Hökaberg, E1 & 23 & 7.5 & 15.53 & 2.91 & 175 & 36.28 & Mälkönen, 1991 \\
\hline Sweden, Hökaberg, E1 & 23 & 7.5 & 12.94 & 2.56 & 220 & 25.24 & Mälkönen, 1974 \\
\hline Sweden, Hökaberg, E1 & 23 & 7.5 & 14.9 & 2.81 & 253 & 28.73 & Mälkönen, 1974 \\
\hline Sweden, Hökaberg, E1 & 23 & 7.5 & 12.68 & 2.45 & 316 & 30.55 & Sudnitsyna, 1967 \\
\hline Sweden, Hökaberg, E1 & 23 & 7.5 & 14.36 & 2.71 & 358 & 25.87 & Sudnitsyna, 1967 \\
\hline UK, Thetford Chase & 31 & 7.8 & 8.28 & 4.01 & 240 & 16.70 & Ovington, 1957 \\
\hline Sweden, Skogaby & 31 & 7.6 & 14.00 & 2.50 & 169 & 14.81 & Persson, 2000 \\
\hline Germany, Solling & 34 & 5.9 & 18.9 & 2.98 & 248 & 12.02 & Cole, 1981 \\
\hline UK, Thetford Chase & 35 & 7.8 & 9.83 & 3.46 & 300 & 11.53 & Ovington, 1957 \\
\hline Italy, Monte di Mezzo & 37 & 8.5 & 16.8 & 2.80 & 147 & 19.01 & Persson, 2000 \\
\hline Sweden, Skåne & 55 & 7.6 & 18.00 & 2.60 & 220 & 11.82 & Nihlgård, 1972 \\
\hline UK, Thetford Chase & 55 & 7.8 & 7.24 & 3.58 & 245 & 14.61 & Ovington, 1957 \\
\hline Czechoslovakia & 70 & 5.5 & 20.6 & 3.25 & 251 & 12.95 & Klimo, 1980 \\
\hline Denmark, Klosterhede & 76 & 7,5 & 15.00 & 1.00 & 188 & 5.31 & Persson, 2000 \\
\hline Russia, Valday & 80 & 5.0 & 25.55 & 2.85 & 526 & 5.41 & Grishina, 1974 \\
\hline Germany, Hoeglwald & 85 & 8.2 & 17.00 & 5.60 & 238 & 23.53 & Recognition \\
\hline Russia, north Dvina & 50 & -0.9 & 12.52 & 2.19 & 140 & 15.62 & Bazilevich, 1983 \\
\hline Russia, Onezhskoe see & 50 & 2.2 & 9.86 & 2.20 & 119 & 18.55 & Bazilevich, 1983 \\
\hline Russia, Valday hejgt & 50 & 4.75 & 13.91 & 2.95 & 127 & 23.31 & Bazilevich, 1983 \\
\hline Russia, Chibiny, $500 \mathrm{~m}$ & 50 & 0.5 & 5.15 & 1.38 & 49 & 27.91 & Bazilevich, 1983 \\
\hline Russia, Gulf Finsky & 50 & 4.1 & 18.28 & 3.39 & 164 & 20.65 & Bazilevich, 1983 \\
\hline Germany, Solling & 87 & 5.9 & 17.9 & 2.90 & 228 & 12.72 & Cole, 1981 \\
\hline France, Aubure & 92 & 5.4 & 9.20 & 2.10 & 129 & 16.32 & Persson, 2000 \\
\hline Germany, Solling & 115 & 5.9 & 12.7 & 2.12 & 161 & 13.17 & Cole, 1981 \\
\hline Sweden Jädraås & $120-150$ & 4.0 & 3.94 & 1.26 & 51 & 24.89 & Bringmark, 1977 \\
\hline Germany, Waldstein & 142 & 5.5 & 16.60 & 4.70 & 242 & 19.45 & Persson, 2000 \\
\hline Czech Republic, Nacetin & 568 & 5.9 & 13.3 & 3.60 & 203 & 17.75 & Persson, 2000 \\
\hline Russia, Arhangel province & 200 & -0.2 & 16.27 & 2.20 & 210 & 10.49 & Marchenko, 1962 \\
\hline
\end{tabular}

